KS. BP Damian Muskus OFM

KRAKÓw

\title{
KOŚCIÓŁ W POLSCE PRZYGOTOWUJE ŚWIATOWE DNI MŁODZIEŻY
}

Jeden z księży pracujących w Komitecie Organizacyjnym ŚDM rozmawiał kiedyś z Yago de la Cierva, dyrektorem wykonawczym ŚDM w Madrycie. „Światowe Dni Młodzieży są jak tornado. Ani się obejrzysz, kiedy porwą cię i pochłoną, całkowicie zmieniając twoje życie - usłyszał wówczas. - Jeśli jesteś gotów na tę zmianę - wejdź w to!". Nie podejmę się jednoznacznej odpowiedzi na pytanie, czy Kościołowi w Polsce potrzebne jest „duchowe tornado”, według metafory użytej przez de la Cierva, ale rację ma ks. Janusz Mariański mówiąc, że potrzebujemy „nowego dynamizmu, by skuteczniej realizować wyzwania nowej ewangelizacji, prowadzącej do ludzkiej i duchowej odnowy"1. Szanse na ten nowy dynamizm Kościoła dają przygotowania do Światowych Dni Młodzieży. Jesteśmy już na ich półmetku i myślę, że warto w kontekście zebranych do tej pory doświadczeń zastanowić się nad tym, czy jesteśmy gotowi na zmiany, jakie mogą przynieść Światowe Dni Młodzieży w Polsce. Czy mamy świadomość szans i wyzwań zawartych w tym wydarzeniu, tak byśmy mogli realizować je jako zadanie, które nie polega jedynie na rozwiązywaniu skomplikowanych kwestii logistycznych, ale nade wszystko winno być wspólną drogą mobilizującą nas wszystkich: biskupów, księży, katechetów, wspólnoty parafialne i młodzieżowe, ewangelizacyjne i modlitewne w całej Polsce. Nie jesteśmy bowiem aktywistami, którzy mają po prostu przygotować duże wydarzenie. Jesteśmy, jak mówił papież Franciszek, narzędziami, dzięki którym tysiące ludzi młodych będzie miało "przygotowaną drogę na spotkanie Jezusa”. Potrzebujemy sił, by sprostać temu zadaniu. Potrzebujemy modlitwy i otwarcia na Bożą łaskę. I nie dotyczy to tylko Komitetu Organizacyjnego ŚDM w Krakowie, ale całego Kościoła w Polsce.

Nigdy dość przypominania o tym, że Światowe Dni Młodzieży nie są zwykłym wydarzeniem, chwilowym wybuchem entuzjazmu i festiwalem wiary, ale drogą, którą zapoczątkował w 1984 roku święty papież Jan Paweł II i zaproponował młodym jako pielgrzymkę przez miasta i kontynenty; pielgrzymkę, w którą włączają się kolejne pokolenia młodych całego świata, by nie tylko siebie przemieniać, ale przez żywe i autentyczne świadectwo wiary przyczyniać się do przemiany Kościołów

1 J. Mariański, Kościół katolicki w przestrzeni życia publicznego, w: Religia i Kościół w społeczeństwie demokratycznym i obywatelskim w Polsce, red. J. Baniak, Poznań 2012, s.100 
lokalnych, które stają się jej etapami. Potwierdzają to zresztą doświadczenia naszych poprzedników. Arcybiskup Rio kard. Orani Tempesta uważa, że ŚDM stały się dla tamtejszego Kościoła prawdziwą wiosną, wydarzeniem, którego owoców nie da się porównać z niczym innym. Wskazywał $\mathrm{m}$. in. na przebudzenie i ogromną mobilizację młodych i starszych Brazylijczyków, ich poczucie wspólnoty i zjednoczenia wokół jednej idei. Tam młodzi doświadczyli żywego Kościoła i teraz szukają w nim miejsca dla siebie - we wspólnotach, w parafiach. Dziś, już po raz drugi w historii, pielgrzymka ŚDM zbliża się do naszego kraju. Jest dla nas darem, bo młodzi są darem dla Kościoła. „Są oknem, przez które dociera świeże powietrze”2 - mówił kard. Stanisław Ryłko podczas spotkania delegatów episkopatów i ruchów kościelnych $\mathrm{z}$ całego świata w Sassone di Campino pod Rzymem, w kwietniu tego roku. Jak ich przyjmiemy? Co możemy im ofiarować w zamian za ich młodzieńczą radość i entuzjazm wiary, którymi będą nas - wierzę w to głęboko - zarażać?

„Przygotowujcie te Dni, mając w pamięci słowa świętego Papieża: Nie lękajcie się! Otwórzcie na oścież drzwi Chrystusowi!”3 - radził nam na tym samym spotkaniu w Sassone przewodniczący Papieskiej Rady ds. Świeckich i podkreślał, że Jan Paweł II jest nie tylko patronem spotkania w Krakowie. Winien stać się również patronem przygotowań do ŚDM. „Pamiętajcie, jak ważnym jest dziś wychodzenie na zewnątrz, do stojących w przedsionku Kościoła, jak ważna jest postawa, którą charakteryzował się miłosierny Samarytanin, jak ważny jest Kościół, który akceptuje każdego"4 - mówił kard. Ryłko, tym samym pomagając w wyznaczeniu mapy drogowej do ŚDM w Krakowie.

\section{Błogosławieństwa programem dla Kościoła w Polsce}

TKoncepcja uczynienia błogosławieństwa programem dla Kościoła w Polsce pochodzi od papieża Franciszka. Podczas ŚDM w Rio poprosił młodych, by wczytywali się w ewangeliczne Błogosławieństwa. Zaproponował rozważanie błogosłwawieństw w czasie kolejnych Światowych Dni Młodzieży, poprzedzających spotkanie w Krakowie w 2016 roku. Ojciec Święty widzi rewolucyjną siłę Błogosławieństw, które - odczytane na nowo w kontekście współczesnych bied i zagrożeń tego świata - mogą stać się dla młodych najpewniejszą gwarancją szczęścia i pięknego, spełnionego życia. Namawia ich do tego wskazując przykład najlepszy z możliwych - Jezusa Chrystusa, który sam szedł drogą Błogosławieństw i jest ich ucieleśnieniem. „Jeśli i wy będziecie umieli powiedzieć Jezusowi «tak», to wasze młode życie wypełni się znaczeniem i tym samym będzie owocne" - przekonywał

\footnotetext{
2 S. Ryłko, Spotkanie delegatów episkopatów i kościelnych w Sassone di Campino (arch. własne autora).

3 Tamże.

4 Tamże.
} 
Franciszek w ubiegłorocznym Orędziu na Światowy Dzień Młodzieży, przebiegający pod hasłem „Błogosławieni ubodzy w duchu, albowiem do nich należy królestwo niebieskie" (Mt 5, 3).

Próbę odczytania Błogosławieństw według klucza, który zaproponował papież Franciszek, podjęli w Archidiecezji Krakowskiej autorzy programu \#B $>$ M (Być to znaczy więcej niż mieć). Gospodarzami tego cieszącego się sporym powodzeniem projektu są krakowskie duszpasterstwa młodzieżowe. Raz w miesiącu zapraszają młodych na spotkanie ze świętym, dla którego idea ubóstwa była ważnym motywem życia, działalności i nauczania. Każdemu z tych spotkań towarzyszy konkretny czyn miłosierdzia: kwesty, zbiórki żywności dla potrzebujących czy ubrań dla bezdomnych. Projekt jest obecny w internecie, ma swój fanpage na FB, a wszystkie materiały audiowizualne oraz konspekty dla prowadzących umieszczone są na stronie internetowej ŚDM, dzięki czemu może być realizowany praktycznie wszędzie, nie tylko w Krakowie. To zaledwie jeden przykład na to, w jaki sposób można przybliżyć młodym papieskie orędzie i zachęcać ich do czytania Błogosławieństw. Z pewnością nie można na nim poprzestawać.

Należałoby zastanowić się nad bardziej pogłębioną i usystematyzowaną analizą przesłania zawartego w papieskim dokumencie, nie tylko w kontekście pracy duszpasterskiej, ale konkretnego zaangażowania społecznego. Ojciec Święty wylicza bowiem problemy, które dotykają i polskie rodziny, co za tym idzie również młodzież w Polsce. To problemy bezrobocia, zniewoleń, emigracji zarobkowej, rozbitych małżeństw, utraconego sensu życia. Z ostatnich wyliczeń Głównego Urzędu Statystycznego wynika, że niemal trzy miliony Polaków żyje w skrajnym ubóstwie ${ }^{5}$. Nie stać ich na zaspokojenie podstawowych potrzeb związanych z wyżywieniem, kupnem odzieży czy opłaceniem rachunków. W Polsce częściej ubóstwem ekonomicznym zagrożeni są ludzie młodzi, w tym dzieci. W 2013 roku wskaźnik zagrożenia ubóstwem skrajnym wśród dzieci i młodzieży do lat 18 wyniósł ok. 10\%, a osoby w tym wieku stanowiły prawie jedną trzecią populacji zagrożonej ubóstwem skrajnym. Jest rzeczą oczywistą, że życie w biedzie utrudnia rozwój dzieci i młodzieży oraz grozi wykluczeniem społecznym ${ }^{6}$. Są to sprawy domagające się wspólnej refleksji i dyskusji środowisk i instytucji, których misją jest poprawa losu współczesnych ubogich. Papież mówi wręcz o nawróceniu wobec ubogich, a od młodych oczekuje wrażliwości i solidarności z potrzebującymi. „Musimy nauczyć się przebywania z ubogimi. Nie wypełniajmy naszych ust ładnymi słowami o ubogich! Spotkajmy ich, spójrzmy im w oczy, wysłuchajmy ich" ${ }^{7}$ - czy to Franciszkowe wołanie zabrzmiało w polskim Kościele dostatecznie głośno i nagląco?

5 Główny Urząd Statystyczny, Departament Badań Społecznych i Warunków Życia, Ubóstwo ekonomiczne w Polsce w 2013 roku, Warszawa 2014

6 R. Szarfenberg, Ubóstwo i wykluczenie - szkic do diagnozy i rekomendacji, Warszawa 2010

7 Franciszek, Orędzie do młodych na XXIX ŚDM, nr 3, www.kdm.org.pl (28.04.2015) 


\section{Czyste serca}

Na drodze ku Światowym Dniom Młodzieży w Krakowie papież Franciszek w sposób szczególny podkreślił jeden z drogowskazów: „Błogosławieni czystego serca, albowiem oni Boga oglądać będą" (Mt 5,8). W Orędziu do młodych na XXX ŚDM (przypadający w roku 2015, w trzydziestą rocznicę ustanowienia Światowych Dni Młodzieży przez papieża Jana Pawła II) Ojciec Święty pisze: „Okres młodości jest czasem, kiedy rozwija się wielkie bogactwo uczuciowe obecne w waszych sercach, głębokie pragnienie prawdziwej miłości, pięknej i wspaniałej. Jak wiele siły jest w tej zdolności do kochania i bycia kochanym! Nie pozwólcie, aby ta cenna wartość została sfałszowana, zniszczona lub oszpecona. Dzieje się tak, gdy w nasze relacje zakrada się instrumentalizacja bliźniego dla własnych egoistycznych celów, czasem jedynie jako obiektu przyjemności. Na skutek tego negatywnego doświadczenia serce ulega zranieniu i smutkowi”. Ze słów papieża przebija troska o młodych, którzy - właśnie z powodu owej żywej tęsknoty do prawdziwej miłości - narażeni są na zwodniczą ułudę „kultury tymczasowości”, która prowadzi do banalizacji miłości i do jej instrumentalizacji. Papież nie waha się: wzywa młodych do buntu: „Wy ludzie młodzi jesteście dzielnymi odkrywcami! Jeśli wyruszycie na odkrywanie bogatego nauczania Kościoła w tej dziedzinie, to odkryjecie, że chrześcijaństwo nie polega na serii zakazów, tłumiących nasze pragnienia szczęścia, ale na planie życia, który może zafascynować nasze serca!". Franciszek nie obwarowuje młodych systemem zakazów i nakazów, ale mobilizuje ich, by sami odkryli piękno miłości prawdziwej i wiernej. Nie pozostawia ich na tej drodze samych i udziela konkretnych odpowiedzi na pytania o szczęście, o spotkanie z Panem, o harmonię świata i czystość serca. „W nowych warunkach społeczno-kulturowych potrzebny jest nie styl dezaprobaty i groźby, lecz pełen miłosiernej troski o formowanie sumień i przekształcanie wiary „dziedziczonej” i z przyzwyczajenia, w wiarę będącą osobistym wyborem, przekonaną i potwierdzoną świadectwem życia” ${ }^{8}$. Papieskie Orędzie do młodych może stać się wzorem wypełnienia tego postulatu w praktyce.

\section{Peregrynacja symboli ŚDM - rekolekcje dla Polski}

Od Niedzieli Palmowej 2014 trwa w Polsce peregrynacja symboli ŚDM - krzyża i ikony Matki Bożej Salus Populi Romani. Tej wędrówce nie towarzyszy spektakularna oprawa medialna, nie jest to także wielka manifestacja wiary, jakiej wielu być może się spodziewało. W ciszy i skupieniu gromadzą się przy symbolach ŚDM wspólnoty ludzi młodych i starszych, modląc się i powierzając miłosiernemu Bogu osobiste sprawy, ale także problemy lokalnych społeczności, w jakich żyją,

8 J. Mariański, Kościót katolicki w przestrzeni życia publicznego, dz. cyt., s. 100. 
dołączając w ten sposób do milionów ludzi na całym świecie, którzy od lat jednoczyli się i wciąż jednoczą przy tych znakach. To bardzo ważny czas dla Kościoła młodych w Polsce. Od jego dobrego przeżycia zależą przyszłe owoce Światowych Dni Młodzieży w Krakowie. Jakże aktualnie w polskiej rzeczywistości brzmią dziś słowa św. Jana Pawła II, który w 1998 roku do młodzieży rzymskiej mówił: „Rozpowszechniona dziś powierzchowna kultura, która przypisuje wartość tylko temu, co ma pozór piękna i co sprawia przyjemność, chciałaby wam wmówić, że trzeba odrzucić Krzyż. Ta moda kulturowa obiecuje sukces i szybką karierę, nakłaniając do realizacji własnych dążeń za wszelką cenę; zachęca do nieodpowiedzialnego przeżywania płciowości i do życia pozbawionego celu, wyzbytego szacunku dla innych. Otwórzcie oczy, młodzi przyjaciele: to nie jest droga prowadząca do

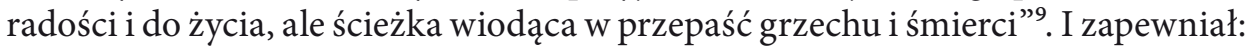
„Jezus jest Miłością wierną, która nie opuszcza nikogo i potrafi przemienić noc w świt nadziei. Jeżeli Krzyż zostaje przyjęty, przynosi zbawienie i pokój, jak to ukazują liczne piękne świadectwa młodych chrześcijan. Bez Boga Krzyż nas przygniata; z Bogiem daje nam odkupienie i zbawienie" "10. Z docierających do Komitetu Organizacyjnego ŚDM w Krakowie sygnałów wynika, że pielgrzymka krzyża i ikony Matki Bożej już przemienia serca. Symbole docierają dosłownie wszędzie: nie tylko do kościołów i na miejskie place, ale też do wiosek dziecięcych, domów pomocy społecznej, na uczelnie, do domów spokojnej starości, szkół, hospicjów i więzień. Te bardzo ludzkie spotkania z krzyżem i towarzyszącym mu wizerunkiem Matki są tak bardzo poruszające, że postanowiliśmy zebrać te świadectwa i stworzyć dokument tego historycznego czasu. Jest jednak i druga, trudniejsza do przyjęcia strona peregrynacji symboli ŚDM w Polsce. Są takie miasta, w których księża i katecheci zauważają, iż młodzi odchodzą od krzyża, opuszczając - chyłkiem lub całkiem otwarcie - miejsce jego adoracji. Po wielu obserwacjach można stwierdzić, że właśnie ci młodzi, wymykający się z auli, sali szkolnej czy kościoła, zadają nam w ten sposób niewygodne, uwierające pytania i zmuszają do tego, by się z nimi zmierzyć. Co robimy nie tak? Dlaczego odchodzą? To symbol krzyża ich zraża czy może nasze metody są zbyt słabe i nieprzystające do oczekiwań młodego człowieka? Warto wyjść za uciekającą młodzieżą, by usłyszeć odpowiedzi na te pytania. Zakładam, że mogą być bolesne, sądzę jednak, że odważna konfrontacja z nimi to pierwszy krok na drodze uzdrawiania naszych relacji z młodymi ludźmi.

\footnotetext{
9 Jan Paweł II, Przemówienie podczas spotkania z młodzieża na pl. św. Jana na Lateranie, w: L'OsRomPol 5-6(1998)

10 Tamże.
} 


\section{Historia i współczesność}

Pięknym zrządzeniem Opatrzności Światowe Dni Młodzieży odbędą się w czasie, gdy polski Kościół będzie świętował 1050. rocznicę chrztu. To nie tylko szansa promocji polskiego dziedzictwa religijnego i kulturowego, ale także możliwość ukształtowania i wzmocnienia patriotycznej tożsamości młodych Polaków, rozbudzenia miłości i szacunku dla tradycji i duchowego bogactwa ojczyzny. Sięgając początków Kościoła w Polsce i otwierając się zarazem na to, co nowe, mamy szansę zachwycić młodych korzeniami, z jakich wyrosła wiara na ziemiach polskich, a ukazując jej zawiłe dzieje przez wieki - ożywić w nich odpowiedzialność i troskę o jej kształt i miejsce w przyszłości.

Interesujący sposób poznawania religijnego dziedzictwa Krakowa i Polski proponuje działający w Komitecie Organizacyjnym ŚDM sektor duszpasterstw akademickich. Otóż, zadaniem jego członków ma być opieka duchowa nad uczestnikami Światowych Dni Młodzieży w Krakowie, towarzyszenie zagranicznym grupom naszych gości i oprowadzanie ich po „duchowych szlakach” Krakowa. Studenci nazywani „aniołami stróżami” - przygotowują się do tej roli przez solidną formację w ramach swoich duszpasterstw, którą potem przekażą wolontariuszom służącym podczas ŚDM jako „aniołowie stróżowie”. Do nich będzie należało też opracowanie propozycji zwiedzania Krakowa według wytyczonych szlaków, np. śladami Jana Pawła II, szlak Bożego Miłosierdzia, Ośmiu Błogosławieństw czy - tak licznych w historii tego miasta - świętych i błogosławionych. Dla naszych studentów udział w takim projekcie to niezwykła okazja, by poznać lub uświadomić sobie na nowo niezwykłe piękno duchowych skarbów naszej Ojczyzny. Jeśli młodzi Polacy zachwycą się tym bogactwem i będą z niego dumni, jeśli będą chcieli bez kompleksów dzielić się nim z rówieśnikami z całego świata, co więcej: zobaczą w nim niewyczerpane źródło inspiracji dla swojej osobistej formacji - program „aniołów stróżów" spełni swoje zadanie.

Jak zresztą pokazują doświadczenia organizatorów wspomnianego już przeze mnie programu \#B $>M$, młodzi ludzie są zainteresowani historią. Z dużym zaangażowaniem i niekłamaną ciekawością poznają dzieje Krakowa opowiadane przez pryzmat świętych związanych z tym miastem, chodzą ich śladami i tropią ukryte w architekturze kościołów symbole duchowości dawnych czasów. Niebagatelne znaczenie ma tu z pewnością fakt, że historie te są przekazywane językiem, który jest dla nich zrozumiały, bo na przykład samo osadzenie projektu w mediach społecznościowych i danie młodym możliwości kręcenia filmików, lajkowania ich i komentowania, powoduje, że angażują się w naturalny dla nich sposób. Zresztą, poszukiwanie języka adekwatnego do porozumiewania się z młodymi ludźmi i ewangelizowania ich wcale nie jest prostą sprawą. Młodzi są odbiorcami wymagającymi i każda nieudolność jest natychmiast bezlitośnie obnażana. Nie przemawiają do nich archaiczne formy języka kościelnego, a próby przekazu ewangelicznych prawd w konwencji języka młodzieżowego nie zawsze są udane. Widać to zresztą 
na portalach społecznościowych, które stały się popularnymi narzędziami ewangelizacji młodych przez młodych. Nastolatek, który stojąc przed kamerą wpada w kaznodziejski ton, nie będzie wiarygodny dla swoich rówieśników, czemu młodzi od razu dają wyraz w komentarzach pod takim filmikiem. Duszpasterz mówiący o niepopularnych prawdach i jednocześnie „robiący oko” do internetowych odbiorców, również nie zyska ich przychylności. Na szczęście jest też sporo przykładów udanych prób takiej komunikacji. Wymienię tylko kilka: 2ryby.pl ks. Mirosława „Maliny” Malińskiego, franciszkańskie Daję Słowo i 3zdania.pl, jezuicki faceBóg i Banita czy dominikańska Langusta na palmie. Znalezienie wspólnego języka z młodymi to duże wyzwanie nie tylko w kontekście ŚDM, może się jednak okazać, że dzięki Światowym Dniom Młodzieży, których aktywność w mediach społecznościowych jest bacznie obserwowana, uda się odkryć, przyswoić i dobrze wykorzystać ciekawe wzorce nowoczesnej komunikacji.

\section{Iść na obrzė̇a}

„Miejcie odwagę iść pod prąd. Miejcie odwagę prawdziwego szczęścia! Powiedzcie «nie» kulturze tymczasowości, powierzchowności i odrzucenia, która nie wierzy, że potraficie podołać odpowiedzialności i zmierzyć się z wielkimi wyzwaniami życia!"11 - przynagla młodych papież Franciszek. Pow tórzył to wezwanie już trzykrotnie: podczas spotkania z wolontariuszami ŚDM w Rio w 2013 roku oraz w obu poświęconych tematowi Błogosławieństw Orędziach do młodych. To pokazuje, jak wielkie znaczenie przywiązuje papież do buntu przeciwko aktualnym trendom kulturowym i cywilizacyjnym. Franciszkowe wezwanie pada na podatny grunt. Młodzi dzisiaj, żyjąc w kulturze nadmiaru dóbr konsumpcyjnych, wrażeń, emocji, rozrywek i informacji, nie bardzo wiedzą, przeciwko komu lub czemu skierować naturalną w tym wieku potrzebę sprzeciwu. W dodatku, stają się coraz bardziej samotni, bo żyjąc w świecie wirtualnym nawiązują w większości tylko pozorne relacji, a nie głębokie więzi. Jeśli jeszcze kilka czy kilkanaście lat temu modne były grupy subkulturowe, z którymi młody człowiek mógł się utożsamić i mieć poczucie przynależności manifestowane sposobem ubierania, fryzurą czy rodzajem słuchanej muzyki, to dziś modne są, wrzucane do portali społecznościowych, „selfie”. Zrobić sobie samemu zdjęcie to pokazać, że to ja jestem dla siebie najważniejszą osobą. Z drugiej strony, „to jak rozpaczliwy krzyk: »spójrz na mnie!«”. Zaczyna się we wczesnym dzieciństwie i wynika z potrzeby przeglądania się w cudzych oczach - twierdzi psychiatra Carole Lieberman ${ }^{12}$. Obserwujemy więc odejście niektórych z tych młodych indywidualistów od regularnych praktyk religijnych,

11 Franciszek, Orędzie na XXIX ŚDM, dz. cyt., nr 2.

12 Zob. A. Żelazińska, Selfie-portret, w: Ja, My, Oni. Poradnik psychologiczny. www.polityka.pl/ jamyoni/1594489,1,zrob-sobie-zdjecie-i-wrzuc-do-sieci-read (28.04.2015) 
bo rytuały i wspólnota ich nie interesują. Nie znaczy to jednak, że nie ma w nich pragnienia Boga. Przeciwnie. Młodzi ludzie potrzebują Go, są w swojej „osobności” coraz bardziej pogubieni i coraz częściej nie wstydzą się do tego przyznać. Stawiają jednak wymagania. Ich pytania są trudne, czasem boleśnie obcesowe, a oni sami oczekują odpowiedzi bezwzględnie szczerych i uczciwych. Nie pójdą za gładkimi słowami, pod którymi się nic nie kryje. Jeśli więc chcemy być dla nich wiarygodni, jeśli chcemy przyciągnąć ich do Kościoła, sami musimy się nawracać. Jeśli chcemy pójść na obrzeża i wyciągnąć rękę do młodych, by ich obudzić, sami potrzebujemy przebudzenia. Mamy być dla nich jak otwarta księga, z której mogą wyczytać prawdę o Jezusie. To warunek podstawowy, bez którego nie uda się nam, duszpasterzom i katechetom, stworzyć dla nich przyjaznego miejsca w Kościele.

Jak mamy przekonać tych niepokornych indywidualistów, samotników mimo woli, do tego, że we wspólnocie nie tracą nic ze swej niepowtarzalności i dopiero dzięki niej mogą naprawdę doświadczyć, co to znaczy być sobą? Światowe Dni Młodzieży, przygotowywane i budowane we wspólnotach wolontariuszy i liderów parafialnych, są szkołą wychodzenia z ciasnych ram egocentryzmu i zapatrzenia w siebie, i szansą na to, by młodzi odkryli, jak niezwykłym bogactwem jest przeżywana wspólnie różnorodność, a „selfie” w grupie przyjaciół wygląda dużo lepiej niż samotny portret, nawet na najpiękniejszym tle.

Nietrudno przy tym zauważyć, że wśród wielu młodych ludzi, nie zawsze skupionych w ruchach i wspólnotach kościelnych, panuje swoista moda na katolicyzm. Ci młodzi sami siebie nazywają „katolickimi hipsterami”, nawiązując do terminologii ukutej na określenie przedstawicieli współczesnej subkultury, której wyznacznikiem jest deklarowana niezależność wobec głównego nurtu kultury masowej i ironiczny stosunek do niego. Są dumni z tego, że stać ich na niezależność myślenia i przeciwstawianie się opiniom większości. Młodych, którzy tworzą katolicką awangardę, jest coraz więcej. Można spotkać ich w internecie, tworzą swoje czasopisma, skupiają się w formalnych i nieformalnych grupach, są inicjatorami nieszablonowych działań ewangelizacyjnych. Wyróżnia ich to, że potrafią cieszyć się swoją wiarą, dzielić się nią spontanicznie i bez wyrachowania. Nie zawsze są rozumiani w Kościele. Bywa, że otwarcie krytykują duszpasterzy i hierarchów. Czasem z nutką wyższości mówią o swoich rówieśnikach zrzeszonych w duszpasterstwach akademickich czy oazach. Za swój autorytet i patrona obrali papieża Franciszka. Powołują się na jego wezwanie: „Nie pękajcie! Budujcie mosty pokoju. Grajcie drużynowo. Wierzcie w lepszą przyszłość pamiętając, że leży ona w waszych rękach! Niech przyszłość doda wam skrzydeł, ale czerpcie też z waszych korzeni: kultury, mądrości, religii, jakie wynieśliście z waszych domów i środowisk. Naprzód - mężnie idźcie w przyszłość!”"13.

Mam nadzieję, że w różnorodnej wspólnocie młodych przygotowujących się do Światowych Dni Młodzieży w Polsce, także oni odnajdą miejsce dla siebie

${ }_{13}$ Cyt. za: Radio Watykańskie, Papież zainaugurowat ogólnoświatowa inicjatywę edukacyjna (2014-09-04). 
i staną się jej oryginalnym, ważnym elementem. Niech więc czują się zaproszeni do współtworzenia tego dzieła. Jeśli się w nim odnajdą, udział w Światowych Dniach Młodzieży umocni ich poczucie przynależności do Kościoła.

\section{Młodzi ożywiają wspólnoty parafialne}

Ale naszą troską winniśmy obejmować nie tylko tych, którzy stoją w przedsionkach Kościoła. Nie wolno nam utracić z oczu młodzieży, która jest blisko: w oazach, grupach modlitewnych, duszpasterstwach młodzieżowych. Wbrew pozorom ich obecność w Kościele wcale nie jest taka oczywista. Ci młodzi są zaangażowani, gorliwi i bardzo twórczy. Jeśli jednak ich energia nie zostanie właściwie ukierunkowana, a oni sami nie będą czuli zainteresowania ze strony kościoła i nie odnajdą swego miejsca we wspólnocie parafialnej, to w końcu się zniechęcą, przygasną i w efekcie zaczną szukać gdzie indziej. Przygotowania do Światowych Dni Młodzieży to dobra okazja, by zadać sobie w związku z tym kilka pytań. Czy my, duszpasterze, katecheci, moderatorzy wspólnot, rzeczywiście potrafimy usłyszeć pragnienia i bolączki naszych młodych przyjaciół, i umiemy na nie odpowiedzieć? Czy zmęczenie, rutyna codzienności, czasem wypalenie nie powodują, że słuchamy nieuważnie, a odpowiadamy powierzchownie? Nie można zapomnieć o pułapce aktywizmu i skupiania się wyłącznie na logistycznych aspektach przygotowań do ŚDM. Taka pułapka grozi jednak także osobom odpowiedzialnym za formację duchową młodych ludzi. Nie wystarczą bowiem pomysłowe, starannie opracowane i atrakcyjnie wydane programy duszpasterskie, plany spotkań w grupach i wspaniałe konspekty katechez. To wszystko na nic, jeśli zabraknie ducha młodości w tych, którzy za młodych są odpowiedzialni. Jestem przekonany, że duchowe i logistyczne przygotowania do Światowych Dni Młodzieży nie są traktowane przez księży jako uciążliwy i narzucony z góry obowiązek, gdyby jednak tak się w tym czy innym miejscu zdarzyło, musimy pamiętać o jednym: młodzi chcą się angażować, droga do ŚDM to dla nich niezwykle ważne i radosne doświadczenie, być może - przyszłość pokaże - przełomowe dla ich życia, a naszym zadaniem jest im umożliwić jak najpełniejsze i najpiękniejsze przeżycie tego czasu. To powinna być wystarczająca motywacja, by szeroko otworzyć przed nimi drzwi. Słuchać ich - i pozwolić im działać. Młodzi potrzebują swoich księży! Jako Komitet Organizacyjny ŚDM zaprosiliśmy młodzież zaangażowaną w parafiach do współpracy. Są oni swoistymi łącznikami między nami a wspólnotami parafialnymi, będą pomagali w godnym przyjęciu pielgrzymów - swoich rówieśników z całego świata. Zdaję sobie sprawę, że często brakuje im doświadczenia czy kompetencji i potrzebują mądrego wsparcia dorosłych. I tu upatruję szansę na ożywienie całej parafii. Ci młodzi ludzie, zarażając innych gorliwością, entuzjazmem i radością wiary, mogą tchnąć nowego ducha w życie parafialne. Jest to potencjał, którego nam nie wolno zmarnować. Komitet Organizacyjny ŚDM zadba o formację i szkolenia dla nich, ale nikt i nic 
nie zastąpi nieocenionego wsparcia, jakie może im dać ich duszpasterz. Nie chodzi przy tym o stworzenie armii doskonale zorganizowanej młodzieży, która będzie wiedziała wszystko o zakwaterowaniu, wyżywieniu i transporcie zagranicznych grup. Chodzi o przygotowanie młodych ludzi, którzy będą dobrymi gospodarzami: świadomymi katolikami, dumnymi ze swojego dziedzictwa i potrafiącymi się dzielić jego pięknem, a zarazem otwartymi na bogactwo kulturowe naszych gości. Tak uformowani młodzi ludzie będą później nieocenionym skarbem i pomocą dla swoich wspólnot parafialnych czy duszpasterskich. Warto więc zainwestować w to trochę czasu i serca.

\section{Wolontariat - nowa jakość}

W tym kontekście ważną kwestią wydaje się obudzenie w młodych ludziach ducha służby. Przyczynić się do tego może wolontariat ŚDM. To szczególnie uprzywilejowana forma uczestnictwa w tym wydarzeniu i wielu młodych zabiega o to, by trafić do grona wolontariuszy. Związane są z tym oczywiście pewne wymagania, np. co do wieku, znajomości języków obcych, umiejętności interpersonalnych i wcześniejszych doświadczeń ŚDM, które powodują, że rekrutacja nie jest automatyczna. Sama możliwość bycia wolontariuszem sprawia jednak, że młodzi zaczynają się zastanawiać nad ideą bezinteresownego oddania czasu i samego siebie w służbie dla drugiego człowieka. Polska młodzież dopiero uczy się wolontariatu i - choć jej zaangażowanie w przeróżne formy bezinteresownej pracy dla innych systematycznie rośnie - ma w tym względzie mniejsze doświadczenia niż rówieśnicy z krajów Europy Zachodniej, gdzie jest to naturalna kwestia stylu życia. Z badań Stowarzyszenia Klon/Jawor wynika, że niemal trzy czwarte młodych osób, nieangażujących się w działalność wolontariacką, przyznaje, że nigdy się wolontariatem nie interesowali, a $70 \%$ twierdzi, że nikt nigdy ich o to nie poprosił. Ponad połowa badanej młodzieży (53\%) dodała też, że nie zna ludzi ani organizacji, z którymi można byłoby podejmować tego typu działania ${ }^{14}$. Przygotowania do ŚDM to dla młodych Polaków wielka szansa, by mogli posmakować, na czym polega wolontariat i sprawić, by nie był tylko ideą, ale po zakończeniu ŚDM stał się składnikiem codzienności, który daje radość, satysfakcję i poczucie spełnienia. Adresujemy do nich program Wolontariat Plus, a jego celem jest właśnie wyzwolenie świadomości prospołecznej, przełamywanie barier, przystosowanie młodych do świata po transformacji, wyrobienie nawyku regularnych spotkań i przekonania o dużym znaczeniu systematyczności. Chcemy zarazić ich pasją społecznego zaangażowania na rzecz innych i ożywić ich aktywność duchem „wyobraźni miłosierdzia”, o którą

14 P. Adamiak, Wolontariat - nie tylko dla herosów, civicpedia.ngo.pl, (2014-10-12) 
prosił na krakowskich Błoniach święty patron ŚDM podczas ostatniej pielgrzymki do Ojczyzny w 2002 roku.

\section{Boże Miłosierdzie}

Zanim kilka milionów młodych ludzi przyjedzie do nas, by poznać i doświadczyć tajemnicy Bożego Miłosierdzia w miejscu, gdzie Pan Jezus przypomniał o niej światu przez św. Faustynę, warto podjąć rachunek sumienia i zapytać, czy rzeczywiście nie brakuje nam dziś „spojrzenia miłości, aby dostrzec obok siebie brata, który wraz z utratą pracy, dachu nad głową, możliwości godnego utrzymania rodziny i wykształcenia dzieci doznaje poczucia opuszczenia, zagubienia i beznadziei (...), aby przyjść z pomocą dziecku zaniedbanemu duchowo i materialnie; aby nie odwracać się od chłopca czy dziewczyny, którzy zagubili się w świecie różnorakich uzależnień lub przestępstwa; aby nieść radę, pocieszenie, duchowe i moralne wsparcie tym, którzy podejmują wewnętrzną walkę ze złem"15? Nie możemy ustawać w uczeniu młodych tej wrażliwości i solidarności z potrzebującymi od podstaw, w środowisku ich życia i dorastania. Nie możemy pozwolić, by z bezradności wobec ludzkiej biedy czy ze zwykłego egocentryzmu przymykali oczy na trudności, z jakimi borykają się ich sąsiedzi czy koledzy z klasy. Hasło ŚDM w 2016 „Błogosławieni miłosierni, albowiem oni miłosierdzia dostąpią” (Mt $5,7)$ winno stać się naszym programem i drogowskazem na czas przygotowań do tego wydarzenia, tak abyśmy z przekonaniem świadczyli przed młodzieżą świata, że tylko miłość zdolna jest wyzwolić ze zła i grzechu, a w Bożym Miłosierdziu jest nasza nadzieja i ocalenie. Podczas Światowych Dni Młodzieży w Krakowie zaprosimy naszych pielgrzymów na wędrówkę do łagiewnickich sanktuariów. Niech pełnymi garściami czerpią tam ze źródeł miłosierdzia, niech przy relikwiach apostołów Bożego Miłosierdzia: św. Faustyny i św. Jana Pawła II doświadczają uzdrawiającej mocy orędzia, które na cały świat płynie z Łagiewnik. Dla nas, dla Kościoła w Polsce i w Krakowie, będzie to niepowtarzalna okazja, by przypomnieć i jeszcze raz uzmysłowić sobie wagę odpowiedzialności, jaką powierzył nam święty Papież, gdy w łagiewnickim sanktuarium zawierzał świat Bożemu Miłosierdziu.

Jednym z elementów logo Światowych Dni Młodzieży jest symbol iskry, która rozbłyska w Krakowie, ale obejmuje swoim płomieniem całą Polskę. I znów powtórzę za świętym Janem Pawłem II: „Trzeba tę iskrę Bożej łaski rozniecać. Trzeba przekazywać światu ogień miłosierdzia"16. Mam nadzieję, że w 2016 roku młodzież ze wszystkich kontynentów poniesie ten ogień do najdalszych zakątków ziemi. Mam nadzieję, że w Polsce rozbłyśnie on pięknym i trwałym blaskiem.

\footnotetext{
15 Jan Paweł II, Homilia podczas Mszy św. i beatyfikacji, Kraków-Błonia, 2002

16 Tenże, Homilia podczas Mszy św. z okazji konsekracji świątyni Bożego Miłosierdzia, Kraków-Łagiewniki 2002
} 


\section{Streszczenie \\ Kościół w Polsce przygotowuje Światowe Dni Młodzieży}

Światowe Dni Młodzieży, które odbędą się w 2016 roku w Krakowie są nie tylko wyzwaniem logistycznym, ale przede wszystkim szansą na duchowe przebudzenie Kościoła w Polsce i wyzwaniem duszpasterskim, które powinno zjednoczyć wszystkich: biskupów, księży, katechetów, wspólnoty parafialne i młodzieżowe, ewangelizacyjne i modlitewne w całej Polsce. Światowe Dni Młodzieży nie są bowiem zwykłym wydarzeniem, ale drogą, którą zapoczątkował w 1984 roku święty papież Jan Paweł II i zaproponował młodym jako pielgrzymkę przez miasta i kontynenty. Włączając się w nią, młodzi ludzie nie tylko siebie przemieniają, ale przez żywe i autentyczne świadectwo wiary przyczyniać się do przemiany Kościołów lokalnych, które stają się jej etapami. Programem duchowych przygotowań do ŚDM stają się dla Kościoła w Polsce Błogosławieństwa, zaproponowane do rozważenia przez papieża Franciszka. Światowe Dni Młodzieży w 2016 i okres przygotowań do tego wydarzenia to wielkie rekolekcje dla całej Polski. Oczekiwanym owocem międzynarodowego spotkania młodych w Polsce jest nowy dynamizm ewangelizacyjny.

Słowa kluczowe: młodzież, papież, duszpasterstwo, ŚDM, miłosierdzie

\section{THE CHURCH IN POLAND PREPARES FOR WORLD YOUTH DAY}

\section{Summary}

World Youth Day that will take place in Krakow in 2016 offers all of us challenges and opportunities. Opportunities for a spiritual awakening of the Church in Poland and a pastoral challenge that should unify everyone: bishops, priests, catechists, parishes, evangelical and prayer communities throughout Poland and the world, and of course, young people. The World Youth Day is not a simple event, but rather an action of authentic and living faith. It began in 1984 by Saint Pope John Paul II when he presented to young people a challenge: a pilgrimage across cities and continents. And in joining that pilgrimage, young people, not only change themselves, but also contribute to a spiritual renewal in their local churches throughout the world. The core message of spiritual preparation for the WYD in Poland is the Beatitudes - the Eight Blessings - that Pope Francis proposed for us to reflect upon. The World Youth Day in 2016, and the preceding period of preparation, will be a huge spiritual retreat for all Poland. The expected fruit of this international encounter will be a new dynamism for Evangelisation.

Key words: youth, pope, pastoral ministries, WYD, mercy

\section{LA CHIESA IN POLONIA ORGANIZZA LA GIORNATA MONDIALE DELLA GIOVENTÜ}

La Giornata Mondiale della Gioventù che si terrà nel 2016 a Cracovia costituisce non solo una sfida logistica, ma soprattutto un'opportunità per un risveglio spirituale della Chiesa in Polonia e per una sfida pastorale che dovrebbe unire tutti: vescovi, sacerdoti, catechisti, comunità parrocchiali e giovanili, comunità evangeliche e di preghiera in tutta la Polonia. La Giornata Mondiale della Gioventù non è quindi un semplice evento, ma 
un cammino a cui ha dato inizio il Santo Papa Giovanni Paolo II nel 1984 e che proposto ai giovani come pellegrinaggio nelle città e continenti. Partecipando a questo cammino i giovani non solo si trasformano,ma attraverso una viva ed autentica testimonianza di fede contribuiscono anche alla trasformazione delle chiese locali che diventano le tappe di questo cammino. Il programma per una preparazione spirituale per la GMG è costituito per la Chiesa in Polonia dalle Benedizioni che sono state proposte da Papa Francesco per una riflessione. La Giornata Mondiale di Gioventù nel 2016 e il tempo di preparazione per questo grande evento sono un ottimo ritiro per tutta la Polonia. Il risultato atteso dall'incontro internazionale dei Giovani in Polonia è un nuovo dinamismo di evangelizzazione.

Parole chiave: giovani, il Papa, la pastorale, la GMG, la misericordia 